\title{
Sovereign Debt Markets in Light of the Shadow Economy
}

\author{
Raphael N. Markellos*, Dimitris Psychoyios ${ }^{\dagger}$ and Friedrich Schneider ${ }^{\ddagger}$
}

\begin{abstract}
We investigate the controversial role of the informal sector in the economy of 64 countries between 2003 and 2007 by focusing for the first time on the impact it has on sovereign debt markets. In addition to a standard ordered probit regression, we employ two nonparametric neural network modelling techniques in order to capture possible complex interactions between our variables. Results confirm our main hypothesis that the informal sector has significant adverse effects on credit ratings and lending costs. MLP neural networks offer the best fit to the data, followed by the RBF neural networks and probit regression, respectively. The results do not change with respect to the stage of economic development of a country and contradict views about the possibility of significant economic benefits arising from the informal sector. Our study has important implications, especially in the context of the ongoing sovereign debt crisis, since it suggests that a reduction in the informal sector of financially challenged countries is likely to help in relaxing credit risk concerns and cutting down lending costs. Finally, a decision tree analysis is used to exploit the inherent discreteness in the data and derive intuitive rules with respect to the level of the informal sector.
\end{abstract}

Keywords: Risk analysis; Finance; OR in banking; Informal Sector; Credit Ratings

JEL Codes: E26, E43, E44, F34, G15, G24, H63.

\footnotetext{
* Norwich Business School, University of East Anglia, UK. Email: R.Markellos@uea.ac.uk

${ }^{\dagger}$ Corresponding Author. Department of Industrial Management, University of Piraeus. 107 Deligiorgi Str., Piraeus, GR 185 34, Greece. Tel: +30 210 4142399. Fax: 210 414-2342. Email: dpsycho@ unipi.gr

* Department of Economics, Johannes Kepler University of Linz. Email: Friedrich.Schneider@jku.at
} 


\section{Introduction}

Tax evasion and the informal sector are highlighted in the press as the root of the sovereign debt crisis in certain countries such as Greece and Portugal. ${ }^{1}$ Rating agencies also emphasize the protagonistic role of the informal sector by justifying recent downgrades of country credit ratings on the basis of pervasive tax evasion. ${ }^{2}$ At an economic policy level, reducing tax evasion in Greece has been one of the key conditions set by the European Union and the International Monetary Fund (IMF) in order to provide a $€ 110 \mathrm{bn}$ bail-out from the debt crisis (e.g., see IMF Country Report No. 10/110, May 2010). Notwithstanding, some concerns have also been voiced about the possible negative side-effects from stamping out tax evasion. ${ }^{3}$ above developments provide the dramatic background for the present paper along with a motivation to try and clarify the unexplored relationship between the informal sector and sovereign debt markets.

The inherently mysterious nature of the informal economy means that its drivers, consequences and theoretical underpinnings remain ambiguous. The term itself is controversial and is encountered also as the economy or sector which is black, grey, shadow, hidden, unrecorded, unreported, illegal, subterranean, underground, parallel, clandestine, second or household. Under a broad definition which focuses only on legal activities, it includes "all economic activities that contribute to the officially calculated (or observed) gross national product but are currently unregistered" (Schneider and Enste, 2000). As discussed in the literature, tax evasion is a key symptom and driver of activities in the informal sector. Much research attempts to understand the links between the formal and informal sector of the economy. However, these concentrate almost entirely on the real sector by looking at positive and negative effects of the informal sector on aspects of the economy which include: competitiveness, income, inequality, corruption, public revenues and policy effectiveness (for reviews see Schneider, 2005; La Porta and Shleifer, 2008).

\footnotetext{
${ }^{1}$ See, for example, "Such (tax) evasion has played a significant role in Greece's debt crisis, and as the country struggles to get its financial house in order, it is going after tax cheats as never before" (Greek Wealth Is Everywhere but Tax Forms, New York Times, Suzanne Daley, May 1, 2010). The informal sector in Greece and Portugal is estimated in 2007 at $26.5 \%$ and $23.5 \%$, respectively, against an average of $18.24 \%$ in the euro zone (estimates by Schneider et al., 2010).

${ }^{2}$ For, example, Moody's downgraded Greece's debt to "highly speculative", from Ba1 to B1, in March 2011 citing "endemic tax evasion" as one of the main reasons for its decision.

${ }^{3}$ See, for example, "Tax evasion. Dues and don'ts. Southern Europe will have trouble increasing its tax take", Economist, August 12, 2010.
} 
In the present paper we explicitly examine for the first time the links between the informal sector and sovereign debt markets. Our main hypothesis is that countries which have larger informal sectors face worse sovereign credit ratings and higher lending costs. This stems from the theoretical and empirical literature which shows the harmful economic effects of the informal sector with respect to, for example, tax revenues, public goods and services, competitiveness, productivity, efficiency and growth. Motivated by Schneider (2005), we also test if the informal sector has an asymmetric impact on sovereign debt markets which depends on the stage of economic development of a country.

As suggested by the current literature on modeling of credit risk (see, for example, Bennell et al., 2006; Sawik, 2012; Elgin and Uras, 2013; Christodoulakis, 2014; Terradez, et al., 2015), our analysis uses both parametric and nonparametric methods along with data mining techniques. In particular, we use order probit regression, MLP and RBF neural networks, and, decision trees. Overall, our empirical results indicate that the informal sector is an important predictor of credit risk in all the approaches considered. Specifically, it has damaging effects for both industrialized and developing countries on credit ratings issued by S\&P, Moody's and Fitch and on lending costs, respectively.

Our analysis provides an important extension to the existing literature. First, it provides modellers, researchers and analysts with a new variable that can be used to improve credit risk predictions and decisions. Second, it shows that MLP neural networks allow the most efficient exploitation of the information in the dataset considered. Standard parametric models cannot deal as successfully with the complexities and behaviour of the data. Moreover, our approach in employing neural network models in assessing the significance of the informal economy is innovative. In particular, we partially overcome the black-box nature of the neural network models by using for the first time variable importance analysis via simulation. Third, investigating the link between the informal and financial sector helps us to better understand the impact of the informal sector on economic development and growth. Sovereign debt markets are fundamental dimensions of financial health, they can significantly amplify or inhibit economic activity and constitute a critical element of the financial sector. It has become clear today that understanding the role of the financial sector, in which sovereign debt plays a key role, is crucial in modelling the economy as a whole (see Brunnermeier and Sannikovy, 2014, inter alia). Moreover, the effectiveness or appropriateness of economic policies can depend significantly on financial market-determined 
variables such as interest rates and investment risk premia (see Akitoby and Stratmann, 2008). Fourth, a variety of stakeholders in the financial sector, both inside and outside a country, which includes financial intermediaries, regulators, policy makers, information brokers, lenders, corporations, risk managers and investors, are interested on the potential effects that the informal sector may have on their decisions and goals which involve sovereign debt (see Ferreira and Gamab, 2007). Fifth, our paper contributes to the important discussion pertaining the widespread evidence concerning the links between corruption, credit ratings and lending costs (see among others, Buttler et al., 2009; Caulkins et al., 2013). In particular, since the informal sector is associated with corruption, it is important to see if and how it also affects debt markets. Finally, given the ongoing sovereign debt crisis in Europe, any new findings about the drivers of country ratings and costs of debt are particularly valuable. It is crucial to understand the function of the informal sector since it may provide a useful policy lever, metric or window of information.

\section{Literature Review}

\subsection{Causes and Effects of the Informal Economy}

The explanations for the emergence of the informal sector are based mainly on the advantages enjoyed by agents operating outside the formal sector. The earliest and most popular of these explanations concentrate on the avoidance of taxes (see, for instance, Eilat and Zinnes, 2002). Latter research considers the importance of the weak rule of law which amplifies corruption in the formal economy (e.g., Johnson et al., 1998; Friedman et al., 2000). Other researchers suggest that the informal economy is fuelled by restrictions related to, for example, bureaucracy, labour or trade regulations (e.g., Friedman et al., 2000; Choi and Thum, 2005), or, by attempts to retain social benefits (Schneider and Enste, 2000). The literature also highlights the fact that agents operating in the informal sector have certain disadvantages in terms of, for example, losing access to certain public services (e.g., legal, security, health, pensions) and private services (e.g., banking, insurance).

The theoretical and empirical literature shows that the informal sector has both negative and positive effects on the economy as a whole (see, among others, Asea, 1996; Schneider and Enste, 2000; Eilat and Zinnes, 2002). As discussed below, it remains undecided if the informal economy has an overall positive or negative influence on economic activity and growth (see Schneider and Enste 2000; Eilat and Zinnes, 2002). 
On the one hand, the expansion of the informal sector shrinks the tax base and revenues. Raising tax rates in order to compensate for the loss in revenues strengthens the incentives to leave the formal sector and may trap economies into a vicious circle. Printing money as a substitute for lost tax revenues is obviously not a long-term solution since it just covers up the problem and eventually leads to inflation and destabilization in the economy. The informal sector becomes a nightmare to macroeconomic policy makers since it increases both model and estimation risk (e.g., Tanzi, 1999), i.e., the uncertainty concerning the correct macroeconomic model and parameter values, respectively. Since informal sector firms operate largely outside the banking system, monetary policy in particular becomes far less effective. Asset allocation and capitalization is also distorted since certain sectors which are better suited for informal sector operation (e.g., commerce, services) become inflated and firms tend to concentrate on shorter-term ventures which have smaller risk and capital expenditures (Kaufmann and Kaliberda, 1996). At the same time, there is unfair competition between firms operating in the informal and formal sector, respectively. The cost of production in the informal sector can be significantly higher since it must include time and money spent on bribes along with the relatively higher costs of informal financing and personal equity. Finally, an important negative social effect of the informal economy is that selective freeriding on public services and unfair competition builds up a socially acceptable distrust against government, official institutions and rule of law (Schneider and Enste, 2000).

On the other hand, possible positive effects of the informal sector have also been discussed in the literature. The main argument here is that it allows economic activity and entrepreneurship when operation in the official sector is not possible or viable due to say excess taxes and regulation or corruption and bureaucracy. Informal sector revenues eventually feed into the formal sector via consumption or savings and therefore ultimately have some positive effect. Finally, under certain conditions it can lead to the creation of markets and the expansion of financial resources. From a neoclassical perspective, the informal sector responds to demand for services and goods and can lead to shifts in competition and efficiency.

In terms of development, La Porta and Schleifer (2008) identify three views about the role of informal sector firms: the "romantic" view (informal sector firms are or can be productive but are held back by various factors related to the economic framework; e.g., de Soto, 2000), the "parasite" view (informal sector firms harm growth since their small scale makes them unproductive and because they take market share from the more productive firms of the formal sector; e.g., see 
studies by the McKinsey Global Institute summarized by Lewis, 2004) and the "dual economy" view (informal and formal sector firms operate in different markets and have different customers and the former supports a large proportion of the poorest population; e.g., Tokman 1992). The authors find empirical support for the third view with big differences between firms across sectors with those in the formal sector being more productive and run by much better educated managers. Although La Porta and Schleifer accept that economic growth is likely to result from the increased productivity of the formal sector, they caution against officialising informal sector firms since their low productivity means that most of them will go out of business with negative effects for employees and owners.

\subsection{Sovereign Debt Credit ratings and Interest Rates}

Abstracting from exchange rate expectations, sovereign debt interest rates ultimately reflect the uncertainty of national revenues along with the willingness of governments to repay back national debt in a timely manner. Sovereign (or country) credit ratings provide standardized forecasts of sovereign debt default probabilities. They became very popular over recent years due the increased demand for information which followed the vast expansion of investment products and services internationally. They also satisfied the more stringent risk management requirements of modern investors which resulted from the complex nature of their exposures and from regulatory changes (e.g., the Basel Capital Accords).

Shifts in credit ratings have widespread economic and financial implications for a country since they are related to the availability and cost of financing at both the country and corporate level. For example, when the rating of Greece was downgraded to "junk" level in April 2010, this led to a sharp increase in the yield to maturity of existing sovereign bonds and to an increase in the interest rate of subsequent debt issues. Since many investors faced regulatory restrictions on the rating of instruments they can hold, the pool of investors for Greek bonds also shrank considerably, especially in the international market, to the extent that intervention by the ECB and IMF became necessary in order to avoid default. Sovereign credit ratings constitute a ceiling and pivot for all the ratings of individual firms operating in the country meaning that they have an impact on the size and cost of corporate financing through debt and equity (Brooks et al., 2004, Cavallo and Valenzouela, 2010). The literature also emphasizes the particular sensitivity of less developed countries to variations in sovereign credit ratings (Kim and $\mathrm{Wu}, 2008$ ). 
Rating agencies mention several economic, social, and political factors underlying their analysis. ${ }^{4}$ However, identifying the effect and importance of each individual criterion is far from straightforward since not all factors are quantifiable, the available proxies are numerous and the weight assigned to each individual criterion is unknown. Since sovereign debt has such prominent economic and financial effects, a large body of empirical literature has concentrated on uncovering the factors behind credit ratings (see, for example, Cantor and Packer, 1996; Hammer et al., 2006; Hilscher and Nosbusch, 2010) and interest rate spreads (see for example Cantor and Packer, 1996; Weigel and Gemmill, 2006). The independent variables examined can be roughly grouped as: liquidity variables (e.g., debt-service-to-export ratio, the interest-service ratio, the liquidity gap ratio), solvency variables, macroeconomic fundamentals (e.g., inflation rate, real exchange rate, GDP growth, CPI, exports growth), external shocks (e.g., changes in US Treasury interest rates, increases in real oil prices, history of defaults) and political variables (e.g., social stability, corruption, legal system, political stability, bureaucracy, terrorism, foreign affairs). The effect of the informal sector on credit ratings and lending costs has not yet been examined in the literature.

\subsection{Modelling Credit Risk}

The modelling of credit ratings belongs to the wider literature on credit risk analysis (see Lessmann et al., 2015, for a recent review). This literature deals with risk at different units of analysis and includes: trade credit scoring models (eg., Terradez, et al., 2015), corporate bond credit ratings (eg., Wang et al., 2014), sovereign credit ratings (Elgin and Uras, 2013, Christodoulakis, 2014) and portfolio risk (eg., Sawik, 2012). The wealth of data on credit ratings has motivated several empirical applications using a variety of parametric statistical methods which include mainly linear regression, logistic regression, multivariate discriminant analysis and ordered probit. However, these parametric approaches have received criticism due to the fact that they make strong assumptions about the functional relationships (linearity) and the distributional properties (normality) of the variables underhand. Although academic theory and credit rating agencies give some rough indications about relevant variables, there is no widely accepted structural model which can be used to justify a particular parametric specification. Motivated by these problems, researchers have also considered nonparametric or semi-parametric alternatives to model credit

\footnotetext{
${ }^{4}$ See, for example, A Guide to Moody's Sovereign Ratings, Moody's (August 2006) and Methodology and Assumptions: Rating International Local and Regional Governments, Standard and Poor's (January 2009).
} 
ratings. These methods are particularly suited to the discrete nature of credit variables and the large size of the relevant datasets. Most of the applications have used neural networks but methods also include, for example, decision trees, fuzzy sets and genetic algorithms. Results suggest that nonparametric methods are more accurate than conventional parametric approaches in modelling credit ratings (see Bennell, et al. 2006, inter alia). The superior empirical fit of nonparametric methods comes at the expense of model transparency, inference and intuition. Although methods do exist for model post-processing, such as sensitivity analysis, simulation and weight analysis, these have not been undertaken in the credit rating analysis literature.

\section{Theoretical Considerations}

Motivated by the adverse economic effects of the informal sector that have been identified in the literature, the main hypothesis in the present paper is the following:

H10: The levels of country credit rating risk and of sovereign debt interest rates are positively associated to the relative size of the informal sector.

As discussed previously, this is justified on the basis that the informal sector reduces valuable tax revenues, limits the effectiveness of economic policy, distorts the efficient allocation of capital, weakens competitiveness and fuels political and social unrest. At the same time, data can be very imprecise about countries with large informal sectors which deepens the information asymmetry between lenders and debtors and adds a premium to interest rates in order to compensate investors for the additional estimation risk. All these factors can be linked with sovereign financial instability and risk and a shift in the likelihood of the state not being able to repay in time its obligations towards its lenders. A rejection of our main hypothesis would lend support to arguments discussed previously about the predominately positive economic effects of the informal sector in terms of say motivating entrepreneurs and other resources. Extending these arguments, it could be that since the informal sector is related to a lower capitalization and financialization of the economy it will make a country to function with smaller operating and financial leverage, both of which are related to smaller risk. Shorter-term projects and less financial leverage means that the economy will be less sensitive to interest rate variations due to a smaller duration and exposure. Moreover, a large informal sector may mean that the national product is underestimated so that sovereign debt ratios appear to be worse than they really are.

We also test the following hypothesis in order to see if the effects of the informal sector depend on the stage of economic development: 
H2a $a_{0}$ For developed countries, the levels of country credit rating risk and of sovereign debt interest rates are inversely associated to the relative size of the informal sector.

H2bo: For developing countries, the levels of country credit rating risk and of sovereign debt interest rates are positively associated to the relative size of the informal sector.

The last two hypotheses suggest that the informal economy has a damaging overall impact on sovereign debt markets of developing countries, while for developed countries the opposite relationship holds. At an empirical level, they are motivated by Schneider (2005) who finds that the size of the informal sector is positively related to economic growth only for industrialized countries. For developing countries he finds a negative such relationship. Since economic growth is a key factor of expectations in sovereign debt markets, there could be a similar effect of the informal sector with respect to the stage of development. As argued by Schneider (2005), there is a theoretical basis for this relationship. In high-income developed countries, entrepreneurship is stifled by excess regulation and taxes so an increase in the informal sector stimulates the official sector and has a positive effect on growth. For low-income, developing countries the informal economy reduces the tax base, public goods and services, which lead to lower growth. This effect on developing countries is consistent with theoretical models and evidence by Asea (1996). Testing for the second set of hypotheses has critical implications at a policy level in the context of the present sovereign debt crisis. If an inverse relationship is true for developed countries, then the widely advocated measure of reducing the informal sector in the developed countries of the Eurozone may have the opposite effect than that anticipated in terms of resolving the debt crisis.

\section{Empirical Application}

\subsection{Sample and Descriptive Analysis}

In order to examine our hypotheses we employ a balanced panel dataset of financial, macroeconomic and other qualitative variables for 64 countries sampled at annual frequency between 2003 and 2007. A brief description of the data and sources is given in Table 1. We also include in this Table for each variable a sign of the effect it is likely to have on credit rating risk and lending costs, respectively, on the basis of previous findings from the literature (a similar categorization is used by Mellios and Paget-Blanc, 2006, Table 1).The countries analysed are grouped into two major categories: 24 developed OECD countries (Australia, Austria, Belgium, Canada, Czech Republic, Denmark, Finland, France, Germany, Greece, Iceland, Ireland, Italy, Japan, Luxembourg, Netherlands, New Zealand, Norway, Portugal, Spain, Sweden, Switzerland, 
United Kingdom, United States) and 40 non-OECD countries (Botswana, Brazil, Bulgaria, Chile, Colombia, Costa Rica, Croatia, Estonia, Ghana, Honduras, Hong Kong, Hungary, India, Indonesia, Israel, Kazakhstan, Latvia, Lebanon, Lithuania, Malaysia, Mexico, Morocco, Pakistan, Panama, Peru, Philippines, Poland, Qatar, Russia, Singapore, Slovenia, South Africa, South Korea, Sri Lanka, Taiwan, Thailand, Trinidad and Tobago, Turkey, Uruguay, Venezuela).

\section{[Insert Table 1 Here]}

The dependent variables used in this study are related to the credit risk and cost of debt for each country. For each country we use 3 different proxies of sovereign credit risk based on credit ratings obtained by three of the largest agencies internationally: Standard and Poor's, Moody's and Fitch. Following Bissoondoyal-Bheenick (2005), among others, credit ratings are mapped into numerical values from 1 to 21 which correspond to country ratings from highest (Moody's "Aaa" and S\&P "AAA" ratings correspond to 1) to lowest (Moody's "C" and S\&P "SD" ratings correspond to 21), respectively. Motivated by the empirical findings in the literature, we include wide variety of different variables in our analysis. Our measure of sovereign cost of debt is the yield to maturity calculated from 10-year benchmark bonds for each country. If such bonds are not available, then we use the closest available maturity. The yield to maturity is estimated as the average of monthly estimates and is represented also as a spread over the yield to maturity of US bonds. In order to proxy the informal sector we employ estimates provided by Schneider et al. (2010). This measure of the informal sector incorporates all market-based goods and services that legally produced but are deliberately concealed in order to evade taxes or other social security contributions and to avoid bureaucratic restrictions. The estimates are obtained via Structural Equation Modelling (SEM) and are expressed as a percentage of GDP for each country.

A descriptive statistical analysis reveals that the credit ratings and costs of debt have a wide variation in our sample. For example, yields (spreads) range between $0.9041 \%$ for Japan in 2003 (-303.42 basis points) to $44.11 \%$ for Turkey in 2003 (4,028.83 basis points) with an overall standard deviation of $4.46 \%$ (436.27 bips). The informal sector averages at just over $26 \%$ of GDP with a maximum of $64.4 \%$ (Panama in 2003) and a minimum of $8.1 \%$ (Switzerland in 2007). The champions in terms of the relatively largest informal sector amongst the OECD countries are Greece (average is $26.86 \%$ across all years), Italy (26.96\%), Portugal (23.12\%), Spain (22.38\%) and Belgium (21.66\%), followed by Norway (18.44\%), Sweden (18.38\%), Denmark (17.46\%) and Finland (17.36\%). The smallest OECD informal sectors are in Switzerland and the US. The 
average relative size of the informal sector in the OECD and Eurozone is $16.02 \%$ and $18.24 \%$, respectively. Almost all variables under study are positively skewed, except for HDI and COMP, while the YTM and SPREAD have extreme variations and are highly kurtotic.

Table 2 gives a further breakdown of average values of the variables across time between OECD and non-OECD countries. On average, advanced economies have better credit ratings and financing costs (YTM of 4.17\% vs. 7.38\%) and smaller informal sectors (16.03\% vs. 31.68\%). Moreover, the results paint a relatively better picture for the advanced economies in terms of all variables considered. It is interesting to observe that ratings and financing costs have improved for both country categories over the period studied. A $t$-test assuming unequal variances suggests that the null hypothesis of no difference in means between the two groups of countries can be accepted at the 5\% level only for GNI, GDPG and REV. Notable changes over the time period under consideration include the expansion in the domestic credit to private sector and the widening of the deficits and current account balances.

A cluster analysis of the variables under study reveals how the shadow economy associates with poor credit quality and economic conditions. Specifically, a K-Means analysis with two clusters identifies that the group of countries with a higher shadow economy on average (34.72\% vs. 19.28\%), has a worse credit rating (in Moody's 10.85 vs.. 3.14) and a higher interest rate (8.82\% vs. $4.37 \%)$ and spread (4.2776\% vs. $0.0117 \%)$, respectively. Moreover, general economic conditions are also adverse with respect to balance of payments (-0.0047 vs. 0.0142), deficit (0.0163 vs. 0.0062$)$, inflation ( $6.52 \%$ vs. $2.64 \%)$, unemployment ( $8.95 \%$ vs. $6.62 \%)$, tax revenues ( $15.84 \%$ vs. $19.98 \%)$, government revenues $(27.71 \%$ vs. $38.61 \%)$, credit to private sector (46.96\% vs. $109.69 \%)$ and R\&D spend ( $0.52 \%$ vs. $1.72 \%)$. Unsurprisingly, as the cluster of countries with higher informal sectors tend to be developing they are smaller in size and have higher growth rates $(6.10 \%$ vs. $4.30 \%)$. Finally, indirect economic indicators also paint a worse picture for the cluster of countries with a higher informal sector, in terms of: competitiveness (3.98 vs. 5.06), economic freedom (58.83 vs. 73.71), corruption (3.65 vs. 7.30) and human development (0.77 vs. 0.92).

\section{[Insert Table 2 and Table 3 Here]}

Table 3 gives the Pearson correlation coefficients of the variables related to credit ratings, cost of debt and the informal sector, respectively. As expected, ratings are closely interdependent with correlations between them approaching unity. Yields are also very strongly correlated to spreads and to ratings. A first conclusion with respect to the hypotheses of our study is that higher levels 
of an informal sector are associated with higher levels of credit risk, as measured by the credit ratings (all correlations above 77\%), and, more expensive sovereign debt (correlation of $42 \%$ with YTM and 39.44\% with SPREAD). The graphical depiction of these relationships for the year 2007 in Figure 1 and Figure 2, respectively, confirms the tight linear relationship. The bivariate regression lines suggest that if Greece, for example, reduces the level of its informal economy to Denmark's level (i.e., from $27 \%$ to $17 \%$ of the GDP which is just below the Euro zone average level of $18.24 \%$ ), then the yield to maturity of benchmark government bonds will be decreased by 112 basis points ( 0.1 times 0.11246$)$, or, equivalently, an improvement of more than 3 notches in the $S \& P$ country credit rating (0.1 times 33.036$)$.

\section{[Insert Figure 1 and Figure 2 Here]}

The remaining correlations are in line with findings of previous studies. The extent of the informal sector correlates with poor economic conditions in terms of current account balance, national income, inflation and unemployment. Economic growth, which is naturally higher for developing countries, is positively correlated to both credit rating risk and the informal sector. Tax revenues and the credit to the private sector are negatively correlated to the informal sector. From the perspective of the other qualitative variables under study, countries with higher informal sectors appear to be: less developed in terms of both human and economic aspects, less competitive, more economically restricted and more corrupt. It is interesting to note that credit ratings, and to a lesser extent costs of debt, have very similar to the informal sector correlations with the other variables in terms of sign and magnitude. We confirm the previously obtained result in the literature that good macroeconomic conditions are associated with better ratings and smaller costs of sovereign debt (see, among others, Cantor and Packer, 1996; Hu et al. 2002). Moreover, there is a strong negative relationship between level of development and competiveness and sovereign debt credit quality (for similar results see Mellios and Paget-Blanc, 2006). The level of corruption is also strongly associated with credit ratings (see Butler and Fauver, 2006; Bissoondoyal-Bheenick, 2005; La Porta et al, 1999; 2008).

\section{[Insert Table 4 Here]}

\subsection{Parametric regression analysis of sovereign credit risk}

In order to test our hypotheses we use credit ratings, yields to maturity and spreads as dependent variables in regressions with the informal sector as an independent variable. In the test regressions we also incorporate a number of other independent variables which are found in the literature to 
have a significant effect. Our "testing-down" estimation strategy adopts a stepwise approach according to which we eliminate variables from the complete original set according to the size of the $t$-statistic until we end up with statistically significant coefficients at the $5 \%$ level. We always retain the informal sector regressor in our models. The estimation results of our "baseline" test regressions appear in Table 4.

For the credit ratings we use an ordered probit estimation procedure since these dependent variables represent ranked categories. ${ }^{5}$ Overall, the results confirm in all regressions estimated our main hypothesis that the informal sector has an adverse effect on sovereign debt markets. Specifically, the positive and statistically significant coefficients attached to INFRM suggest that higher levels of informal sector are associated with worse credit ratings and lending costs. Overall, the dependent variables appear to be influenced by a similar set of variables and the sign of the effects is in most cases in line with what has been previously reported in the literature (see also the theoretical sign predictions given in Table 1). Corruption, which is linked to the informal sector and has been found to significantly influence sovereign debt markets, enters also as a significant regressor with an adverse effect in three out of the five test regressions estimated. The magnitude of the impact that the informal sector has in comparison to the other independent variables is significant if measured in terms of elasticity. Specifically, the elasticities attached to the informal sector are $0.29,0.3179,0.2926,0.1559$ and 0.4742 which are much higher or equal in four cases when compared the average elasticities of $0.1423,0.1422,0.1222,0.2523$ and 0.4737 for the five test regressions in Table 4, respectively.

We now turn to our second set of hypotheses which allow for an asymmetric effect of the informal sector depending on the stage of economic development. In Table 5 and Table 6, we summarize the regression analysis results for the sample of OECD and non-OECD countries, respectively. In all cases except one, the spread for the non-OECD countries, we cannot confirm an asymmetric relationship since the coefficient attached to the informal sector is consistently positive. These findings are in line with the correlation analysis in the sample of OECD and nonOECD countries. On the basis of these results, we reject our second set of hypothesis that the effect of the informal sector depends on the stage of economic development.

\footnotetext{
${ }^{5}$ Comparable results are obtained, available upon request, even if we assume continuity of the dependent variable and estimate these regressions via least squares. In these regressions adjusted R-squared coefficients exceed $90 \%$.
} 


\section{[Insert Table 5 and Table 6 Here]}

The strong correlations found previously in the descriptive analysis between our independent variables indicate that the validity of our estimation and results may be influenced by collinearity. Indeed, several of the uncentred variance inflation factors (results available upon request) for the baseline regression coefficients assume values well above the widely used threshold of 10. In order to address this problem, we undertake a principal component analysis (PCA) of all our variables, excluding the informal sector and those used as dependent variables previously, in order to try and repackage the information contained in the data within independent variables which will then be used in our test regressions. The results of the PCA, summarized in Table 7, indicate the presence of seven significant factors with an eigenvalue above unity which explain a total of $73.25 \%$ of the variation in the dataset. These factors are then used along with the informal sector as regressors against credit ratings and lending costs. The same estimation strategy is employed as previously and the results are given in Table 8 . The results again suggest that the relative size of the informal sector is linked to poorer credit ratings. However, no statistically significant relationship is found now with the two variables measuring sovereign cost of debt. So, our main hypothesis is again partially supported by the data if we correct for multicollinearity using PCA.

\section{[Insert Table 7, and Table 8 Here]}

Since we are dealing with a balanced panel dataset it is also reasonable to evaluate the use of fixed and random effects in the regression analysis. However, panel regression offers comparable results and inferences (results available upon request) while test statistics do not offer conclusive guidance about the necessity of using a panel approach. Finally, motivated by the differences across time found in the descriptive analysis of average values, we investigate the stability of the estimated regressions. We apply a Chow test using as breakpoints the end of 2003, 2004, 2005 and 2006 in our sample which we use to estimate the pooled baseline regressions. The results cannot reject the null hypothesis of constant coefficients across periods for all the regressions estimated.

\subsection{Neural network analysis of sovereign credit risk}

We now turn to a non-parametric analysis of our data using the neural network class of models. Such models have been successfully applied in the literature and industry for several years to predict credit ratings for firms and countries and have been found to be superior compared to conventional parametric approaches (eg., see Bennel et al., 2005, inter alia). The rationale for using neural networks in this area is based on the complexity of the relationships involved and fact 
that they require minimal assumptions about the data. Rather than using them solely for prediction, we use neural networks in an innovative manner in the present paper in order to evaluate the importance of the shadow economy as a predictor of sovereign credit ratings and costs. The neural network analysis allows us to control not only for the other variables but also for the possibility of complex inter-relationships in the data and the violations of assumptions made by the parametric models used in the previous section.

Two of the most commonly used neural networks were considered in the analysis: Multi-layer Perceptrons (MLPs) and Radial Basis Functions (RBFs). In order to avoid overfitting a crossvaluation method was adopted where $70 \%$ of the sample was used for model parameter optimisation (training) while the remaining was left for testing. In line with the standard approach in this literature, the optimisation process was stopped when the model error started to increase in the testing sample in order to avoid overfitting. A standardised rescaling method was used for the continuous variables in the sample. For the MLPs we used a hyperbolic tangent and identity activation function in the hidden and output layer, respectively, with a cross-entropy error function. The initial learning rate and momentum were set at 0.4 and 0.9 , respectively. For the RBFs, we use a softmax and identity activation function in the hidden and output layer, respectively, with a sum of squares error function. The "best" number of hidden units is the one that yields the smallest error in the testing data. All models estimated included one hidden layer with a limited number of units that ranged between 3 and 17. The results suggested that the MLPs had a far superior performance in modelling the five depend variables under study with the R-squared values over the testing and training sample being: $95.75 \%$ (RTGSP), 95.94\% (RTGF), 86.65\% (RTGM), $92.38 \%$ (YTM) and $74.66 \%$ (SPREAD), respectively (the corresponding numbers for the RBFs are $84.79 \%, 86.36 \%, 61.28 \%, 35.70 \%$ and $36.22 \%$, respectively).

In order to assess the relative value of the shadow economy in the neural network models estimated, an independent variable importance analysis was performed. This analysis is based on simulation as the complexity of the neural network models means that the predictive value of each variable cannot be evaluated directly as with parametric models. This computationally intensive approach assesses the relative importance of each independent variable used in the model over the training and testing sample. The importance is measured by the magnitude of change in the dependent variable that is produced by a simulated change in a particular independent variable. 
The results for the MLP presented in A star (dagger) denotes statistical significance at the 1\% (5\%) level. The models for RTGSP, RTGF and RTGM are estimated via maximum likelihood using pooled ordered probit regression; for the remaining OLS was used.

Table 9 are in line with the parametric analysis in the previous section and indicate that the shadow economy in all cases is one of the most important predictors. In particular, out of the 27 independent variables considered, the shadow economy ranked in position: 4 (RTGSP), 7 (RTGF), 7 (RTGM), 12 (YTM) and 13 (SPREAD), respectively. Even better results were obtained from the RBFs with the shadow economy ranking within the top 10 most important variables for all dependent variables modelled (results are omitted in order to preserve space but are available upon request).

\section{[Insert Table 9 Here]}

\subsection{Decision tree analysis of sovereign credit risk}

The final step in our empirical study uses decision tree analysis to gain further insight on the effects of the shadow economy on sovereign credit ratings and yields. This allows us also to exploit the inherent discreetness in our data and to extract intuitive rules that could be of practical use for decision makers. In particular, we consider the problem of using the informal economy and other variables in our dataset to classify the credit ratings as either investment grade (INVG) or junk (JNK). This binary classification facilitate the analysis and corresponds to a convention that is widely used in the financial industry. Although the credit rating scale used in the previous analysis can be assumed to be approximately continuous, the reality is that the qualitative difference between investment grade and junk can be dramatic despite the fact that they lie on the same overall scale. For example, this is the cut-off point used by many funds when screening potential investments.

We considered three of the main tree growing methods: CHAID (Chi-squared Automatic Interaction Detection), CRT (Classification and Regression Trees) and QUEST (Quick, Unbiased, and Efficient Statistical Tree). Although comparable results were drawn from different methods, we finally decided to adopt the CHAID method as it allows multiway node splitting. The method works by selecting the independent variable that has the strongest interaction with the dependent variable. All possible splits for each independent variable are evaluated and categories are merged if they are not significantly different with respect to their interaction with the dependent. A likelihood ratio was chosen in order to determine node splitting and category merging. 
The results of the analysis for the Moody's ratings is shown in Figure 3. The tree used 12 nodes ( 8 of which are terminal) and a depth of three levels to achieve an impressive classification rate of over $94 \%$ ( $97 \%$ for INVG and $85.9 \%$ for JNK). With respect to the shadow economy, three distinct nodes appear in the first level. Countries with an informal sector (INFRM) less than 17.9\% (terminal Node 1) are classed as having an investment grade rating. For countries with an informal sector between $17.9 \%$ and $31.7 \%$, inflation (INFL) is the decisive factor in the second level. In particular, countries with a low inflation (less than 6.88\%) are classified as having an investment grade rating whilst the remaining are considered at the junk level. For countries that have an informal sector over $31.7 \%$ (Node 3), the relative level of public debt (PDGDP) determines the classification. A level of debt under $24.9 \%$ (over 52\%) of the GDP leads to an investment grade (junk) classification. For the mid-range of public debt (Node 8) the decisive factor in the $3^{\text {rd }}$ level is if the country adopts a French legal system or not, something that can be associated to colonial history. Overall, the results are intuitive and demonstrate the value of the shadow economy as a key variable in classifying the creditworthiness of a country. The shadow economy does not create credit problems for levels under around 18\%. For higher levels of the shadow economy, up to $32 \%$, credit problems will appear if inflation is high (over around 7\%). At even higher levels of the informal economy, the only way to avoid credit problems is to have a lower level of public debt (less than around $25 \%$ of GDP).

\section{Conclusions}

This paper investigates for the first time the empirical links between the informal sector and sovereign debt markets using parametric and nonparametric methods. The results confirm our main hypothesis that larger informal sectors with respect to the GDP of a country can be associated with worse credit ratings and higher costs of debt, respectively. Results are consistent between the alternative parametric and nonparametric methods used. In terms of model fit, we find that MLP neural networks have the superior performance, followed by RBF neural networks and probit regression, respectively. This finding extends previous results in the literature concerning the adverse economic effects of the informal sector. According to our analysis, the impact of the informal sector does not change between industrialized OECD and non-OECD countries. Our analysis also derives intuitive credit risk decision rules on the basis of the shadow economy.

Overall, our results lend support to the recently advocated policies of reducing the informal sector in the countries of the Eurozone that face a sovereign debt crisis. It does not appear that 
sovereign debt market participants see any benefits in the informal sector. Additional research is needed in order to further understand and theoretically model the economic mechanism through which the informal sector impacts the financial sector in general. Also, it is important to investigate the short-term effects and causalities between the informal sector and financial markets in general. Finally, a caveat in our analysis is that due to lack of data our sample did not include the global economic crisis period. Future research could investigate the impact of reducing the informal sector when countries face financial difficulties such as an economic recession or pressures in the debt market.

\section{References}

Akitoby, B., Stratmann, T., 2008. Fiscal Policy and Financial Markets. The Economic Journal 118, 1971-1985.

Asea, P.K., 1996. The informal sector: baby or bath water? A comment. Carnegie-Rochester Conference Series on Public Policy 45, 163-71.

Bennell, J.A., Crabbe, D., Thomas, S., ap Gwilym, O., 2006. Modelling sovereign credit ratings: Neural networks versus ordered probit, Expert Systems with Applications 30, 415-425

Bissoondoyal-Bheenick E., 2005. An analysis of the determinants of sovereign ratings. Global Finance Journal 15, 251-280.

Brooks, R., Faff, R., Hillier, D. Hillier, J., 2004. The national market impact of sovereign rating changes. Journal of Banking and Finance 28, 233-250.

Brunnermeier, K.M., Sannikovy, Y., 2014. A macroeconomic model with a financial sector. American Economic Review 104, 379-421.

Butler, A.W., Fauver, L., 2006. Institutional environment and sovereign credit ratings. Financial Management 35, 53-79.

Cantor, R., Packer, F., 1996. Determinants and impact of sovereign credit ratings. Economic Policy Review 2, 37-53.

Caulkins, J.P., Feichtinger, G., Grass, D., Hartl, R.L. Kort, P.M. Novak, A.J., Seidl, A. 2013. Leading bureaucracies to the tipping point: An alternative model of multiple stable equilibrium levels of corruption. European Journal of Operational Research 225, 541-546.

Cavallo, E.A., Valenzouela, P., 2009. The determinants of corporate risk in emerging markets: an option-adjusted spread analysis, International Journal of Finance and Economics 15, 59-74. 
Choi, J.P., Thum M., 2005. Corruption and the shadow economy. International Economic Review 46, 817-36.

Christodoulakis, G., 2014. Rating Agencies vs. Sovereign Debt Markets. Managing Risks in the European Periphery Debt Crisis. In G. Christodoulakis (Ed.) Managing Risks in the European Periphery Debt Crisis (pp.78-86)

de Soto, H., 2000. The mystery of capital. Why capitalism triumphs in the west and fails everywhere else. New York: Basic Books.

Eilat, Y., Zinnes, C., 2002. The shadow economy in transition countries: Friend or foe? A Policy Perspective. World Development 30, 1233-1254.

Elgin, C., Uras, B.R., 2013. Public debt, sovereign default risk and shadow economy. Journal of Financial Stability 9, 628-640.

Ferreira, M.A., Gamab, P.M., 2007. Does sovereign debt ratings news spill over to international stock markets? Journal of Banking and Finance 31, 3162-3182.

Friedman, E., Johnson, S., Kaufmann, D., Zoido-Lobaton, P., 2000. Dodging the grabbing hand: the determinants of unofficial activity in 69 countries. Journal of Public Economics 76, 459-493. Hammer, P.L, Kogana, A. Lejeunec, M.A., 2006. Modeling country risk ratings using partial orders. European Journal of Operational Research 175, 836-859.

Hilscher, J., Nosbusch, Y., 2010. Determinants of sovereign risk: Macroeconomic Fundamentals and the pricing of sovereign debt. Review of Finance 14, 235-262.

Hu Y-T., Kiesel R., Perraudin W., 2002. The estimation of transition matrices for sovereign credit ratings. Journal of Banking and Finance 26, 1383-1406.

Johnson, S., Kaufmann, D., Zoido-Lobaton, P., 1998. Regulatory discretion and the unofficial economy. American Economic Review 88, 387-392.

Kaufmann, D., Kaliberda, A., 1996. Integrating the unofficial economy into the dynamics of post socialist economies: A framework of analyses and evidence. In B. Kaminski (ed.), Economic Transition in Russia and the New States of Eurasia, London: M.E. Sharpe, 81-120.

Kim, S., Wu, E. 2008. Sovereign credit ratings, capital flows and financial sector development in emerging markets. Emerging Markets Review 9, 17-39.

La Porta R, Lopez-de-Silanes, F., Shleifer, A., Vishny, R., 1999. The quality of government. Journal of Law, Economics, and Organization 15, 222-79. 
La Porta, R., Lopez-de-Silanes, F., Shleifer, A., Vishny, R. 2008. The economic consequences of legal origins. Journal of Economic Literature 46, 285-332.

La Porta, R., Shleifer, A., 2008. The unofficial economy and economic development, Working Paper, National Bureau of Economic Research 14520.

Lessmann, S. Baesens, B., Seow, H.-V., Thomas, L.C., 2015. Benchmarking state-of-the-art classification algorithms for credit scoring: An update of research. European Journal of Operational Research 247, 124-136.

Lewis, W., 2004. The power of productivity: Wealth, poverty, and the threat to global stability. Chicago: University of Chicago Press.

Mellios, C., Paget-Blanc, E., 2006. Which factors determine sovereign credit ratings? European Journal of Finance 12, 361-377.

Rose-Ackerman, S., 2002. 'Grand' corruption and the ethics of global business. Journal of Banking and Finance 26, 1889-1918.

Sawik, B., 2012. Downside Risk Approach for Multi-Objective Portfolio Optimization. In D. Klatte et al.(Eds.) Operations Research Proceedings 2011 (pp.191-196).

Schneider, F., 2005. Shadow economies around the world: what do we really know? European Journal of Political Economy 21, 598-642.

Schneider, F., Buehn, A., Montenegro, C.E., 2010. New Estimates for the Shadow Economies all over the World. International Economic Journal 24, 443-461.

Schneider, F., Enste, H.D., 2000. Shadow economies: Size, causes, and consequences. Journal of Economic Literature 38, 77-114.

Tanzi, V., 1999. Uses and abuses of estimates of the underground economy. Economic Journal 109, 338-347.

Terradez, M., Kizys, r., Juan, A., Debon, A.M., Sawik, a., 2015. Risk Scoring Models for Trade Credit in Small and Medium Enterprises. In C.P. Kitsos, T.A. Oliveira, A. Rigas \& S. Gulati (Eds) Springer Proceedings in Mathematics \& Statistics Vol. 16 (pp.349-360).

Tokman, V.E., 1992. Beyond regulation: The informal sector in Latin America. Bolder: Lynne Rienner Publishers.

Wang, C-J, Dai, T-S, Lyuu, Y-D., 2014. Evaluating corporate bonds with complicated liability structures and bond provisions, European Journal of Operational Research 237, 749-757. 
Weigel, D., Gemmill, G., 2006. What drives credit risk in emerging markets? The roles of country fundamentals and market co-movements, Journal of International Money \& Finance 25, 476-502. 
Table 1. Variable acronyms, short descriptions, data sources and expected impact. A sign $+(-)$ indicates that a positive (negative) relationship is expected between the variable and the risk of default according to findings from the previous literature (eg., see Mellios and Paget-Blanc, 2006).

\begin{tabular}{|c|c|c|c|}
\hline Variable & Description & Source & Effect \\
\hline $\begin{array}{l}\text { RTGSP, RTGM, } \\
\text { RTGF }\end{array}$ & $\begin{array}{l}\text { Sovereign credit ratings assigned by S\&P, Moody's and Fitch, respectively. In line with Bissoondoyal-Bheenick (2005), among others, the ratings } \\
\text { are transformed to numerical equivalents with a higher value representing a higher level of credit risk and a higher probability of default. }\end{array}$ & $\begin{array}{l}\text { S\&P, Moody’s, } \\
\text { Fitch. }\end{array}$ & \\
\hline YTM & The yield to maturity of a 10-year zero coupon benchmark government bond multiplied by 100 . If none available the closest maturity is selected. & Bloomberg & \\
\hline SPREAD & The spread in terms of basis points between the YTM of each country under consideration and that of the US YTM. & & \\
\hline INFRM & Informal sector as a percentage of GDP based on the estimates of Schneider et al. (2010) for the period 2003 to 2007. & $\begin{array}{l}\text { Schneider et al. } \\
(2010)\end{array}$ & \\
\hline BLNC & Current account balance: sum of net exports, net income, and net current transfers. Expressed as \% of GDP. & World Bank & - \\
\hline DFCT & Cash surplus or deficit: revenues minus expenses and net acquisition of nonfinancial assets. Expressed as \% of GDP. & World Bank & - \\
\hline RD & $\begin{array}{l}\text { Expenditures (both public and private) for research and development (R\&D). Covers basic research, applied research, and experimental } \\
\text { development. Expressed as \% of GDP. }\end{array}$ & $\begin{array}{l}\text { World Bank, } \\
\text { EUROSTAT }\end{array}$ & - \\
\hline GNI & $\begin{array}{l}\text { Gross National Income: value of the gross balance of primary incomes for all sectors. GNI is equal to GDP less taxes on production and imports, } \\
\text { employees' compensation and property income payable to the rest of the world plus items receivable from the rest of the world. Log transformed. }\end{array}$ & World Bank & - \\
\hline GDPG & $\begin{array}{l}\text { Gross Domestic Product Growth: GDP is the sum of gross value added by all resident producers in the economy plus any product taxes and minus } \\
\text { any subsidies not included in the value of the products. }\end{array}$ & $\begin{array}{l}\text { Euromonitor } \\
\text { International }\end{array}$ & - \\
\hline TAX & Tax revenue. Expressed as \% of GDP. & World Bank & $+/-$ \\
\hline REV & $\begin{array}{l}\text { Government Revenue: taxes, social contributions, grants receivable, and other revenue. Revenue increases government's net worth, which is the } \\
\text { difference between its assets and liabilities. Expressed as \% of GDP. }\end{array}$ & IMF & - \\
\hline CRED & $\begin{array}{l}\text { Credit to private sector: financial resources provided to the private sector, such as through loans, purchases of nonequity securities, and trade } \\
\text { credits and other accounts receivable, that establish a claim for repayment. Expressed as \% of GDP. }\end{array}$ & World Bank & + \\
\hline FDGDP & $\begin{array}{l}\text { Foreign government or public debt: money one country owes to another country, as a result of loans and/or a negative balance of trade. Expressed } \\
\text { as \% of GDP. }\end{array}$ & IMF & + \\
\hline PDGDP & $\begin{array}{l}\text { Public Debt: total gross debt owed by any level of government. Debt is reported at values outstanding at the end of the year and is consolidated } \\
\text { between and within the sectors of general government. Expressed as \% of GDP. }\end{array}$ & IMF, OECD & + \\
\hline INFL & The rate of inflation. & World Bank & + \\
\hline UNPL & The unemployment rate & World Bank & + \\
\hline HDI & $\begin{array}{l}\text { United Nation's Human Development Index. It approximates the standard of living and human development. It takes into consideration variables } \\
\text { such as life expectancy, education, GDP per capita, etc. Assumes values from } 0 \text { (least developed) to } 1 \text { (most developed). }\end{array}$ & United Nations & - \\
\hline CRPT & $\begin{array}{l}\text { The Corruption Perceptions Index. It estimates the public sector corruption in a particular country. It is constructed by compiling expert's } \\
\text { assessments and business surveys and ranges from zero (highly corrupt) to ten (highly clean). }\end{array}$ & $\begin{array}{l}\text { Transparency } \\
\text { International }\end{array}$ & - \\
\hline COMP & $\begin{array}{l}\text { The Growth Competitiveness Index. It estimates the competitiveness of a country or, equivalently, its growth potential. It is affected by the } \\
\text { macroeconomic environment, the quality of public institutions and technological progress. Higher values indicate more competiveness. }\end{array}$ & $\begin{array}{l}\text { World Economic } \\
\text { Forum }\end{array}$ & - \\
\hline $\begin{array}{l}\text { EURO, OECD, } \\
\text { NONOECD }\end{array}$ & $\begin{array}{l}\text { State of the economy dummy variable. OECD, NONOECD and EURO correspond to OECD member countries, countries that do not belong to } \\
\text { OECD and Eurozone member countries, respectively. }\end{array}$ & & $+/-$ \\
\hline $\begin{array}{l}\text { DFLT75, } \\
\text { DFLT95 }\end{array}$ & $\begin{array}{l}\text { Dummy variables of default. S\&P identifies three types of default: local currency debt, foreign currency bond debt, and foreign currency bank } \\
\text { debt. DFLT75 takes the value of one if a country defaults on any of the above types of debt, and zero otherwise during the time period from } 1975 \\
\text { to 2007. Similarly for DFLT95 during the time period from } 1995 \text { to } 2007 \text {. }\end{array}$ & $\mathrm{S} \& \mathrm{P}$ & + \\
\hline FRDM & $\begin{array}{l}\text { The Index of Economic Freedom. It ranges from } 0 \text { to } 10 \text { with the highest value indicating that the country's economic freedom provides an } \\
\text { absolute right of property ownership, fully realized freedoms of movement for labor, capital, and goods, and an absolute absence of coercion or } \\
\text { constraint of economic liberty beyond the extent necessary for citizens to protect and maintain liberty itself. }\end{array}$ & $\begin{array}{l}\text { The Heritage } \\
\text { Foundation }\end{array}$ & - \\
\hline LGL('X') & $\begin{array}{l}\text { Dummy variables that show the origin of the country's legal system. LGLFRC, LGLGRM, LGLSKN, LGLSOC, and LGLUK take the value of } \\
\text { one if the country's legal system is respectively originated from English, French, German, Scandinavian, and Socialist type of law, respectively, } \\
\text { and zero if otherwise. }\end{array}$ & $\begin{array}{l}\text { La Porta et al. } \\
(1999) .\end{array}$ & $+/-$ \\
\hline
\end{tabular}


Table 2. Average values per year for OECD (upper line) and non-OECD countries (bottom line).

\begin{tabular}{|c|c|c|c|c|c|c|c|c|}
\hline & 2003 & 2004 & 2005 & 2006 & 2007 & $\begin{array}{c}\text { Average } \\
\text { All Years } \\
\end{array}$ & t-test & $\begin{array}{c}(2003-20007) \\
\% \text { change }\end{array}$ \\
\hline \multirow{2}{*}{ RTGSP } & 1.8696 & 1.7826 & 1.7826 & 2.0417 & 2.1250 & 1.9203 & \multirow{2}{*}{0.0000} & $13.66 \%$ \\
\hline & 10.1026 & 9.7179 & 9.3077 & 9.1579 & 9.0000 & 9.4572 & & $-10.91 \%$ \\
\hline \multirow{2}{*}{ RTGF } & 1.9565 & 1.7826 & 1.7826 & 1.9583 & 2.0000 & 1.8960 & \multirow{2}{*}{0.0000} & $2.22 \%$ \\
\hline & 10.1282 & 9.7179 & 9.3077 & 9.1579 & 8.9474 & 9.4518 & & $-11.66 \%$ \\
\hline \multirow{2}{*}{ RTGM } & 1.3913 & 1.3913 & 1.3913 & 1.5417 & 1.5417 & 1.4515 & \multirow{2}{*}{0.0000} & $10.81 \%$ \\
\hline & 9.6410 & 9.3846 & 9.2821 & 9.2368 & 8.9737 & 9.3036 & & $-6.92 \%$ \\
\hline \multirow{2}{*}{ YTM } & 4.3920 & 4.4623 & 3.9222 & 3.7540 & 4.3109 & 4.1683 & \multirow{2}{*}{0.0000} & $-1.85 \%$ \\
\hline & 8.3657 & 7.7088 & 7.1463 & 6.9048 & 6.7801 & 7.3811 & & $-18.95 \%$ \\
\hline \multirow{2}{*}{ SPREAD } & 0.5636 & 0.1986 & -0.2974 & -0.6436 & -0.3991 & -0.1156 & \multirow{2}{*}{0.0000} & $-170.81 \%$ \\
\hline & 4.5373 & 2.3502 & 2.9267 & 2.5072 & 2.0701 & 2.8783 & & $-54.38 \%$ \\
\hline \multirow{2}{*}{ INFRM } & 0.1627 & 0.1612 & 0.1605 & 0.1591 & 0.1578 & 0.1603 & \multirow{2}{*}{0.0000} & $-3.01 \%$ \\
\hline & 0.3261 & 0.3208 & 0.3162 & 0.3135 & 0.3075 & 0.3168 & & $-5.70 \%$ \\
\hline \multirow{2}{*}{ GNI } & 13.0355 & 13.0941 & 13.1468 & 13.1540 & 13.2117 & 13.1284 & \multirow{2}{*}{0.8131} & $1.35 \%$ \\
\hline & 11.0357 & 11.1515 & 11.2629 & 11.3748 & 11.5028 & 11.2655 & & $4.23 \%$ \\
\hline \multirow{2}{*}{ GDPG } & 0.0177 & 0.0334 & 0.0285 & 0.0341 & 0.0354 & 0.0298 & \multirow{2}{*}{0.0808} & $100.00 \%$ \\
\hline & 0.0512 & 0.0666 & 0.0576 & 0.0712 & 0.0707 & 0.0635 & & $38.09 \%$ \\
\hline \multirow{2}{*}{ BLNC } & 0.0126 & 0.0119 & 0.0040 & -0.0021 & -0.0047 & 0.0043 & \multirow{2}{*}{0.0000} & $-137.30 \%$ \\
\hline & 0.0036 & 0.0004 & 0.0065 & -0.0003 & 0.0068 & 0.0034 & & $88.89 \%$ \\
\hline \multirow{2}{*}{ DFCT } & -0.0093 & -0.0062 & 0.0028 & 0.0097 & 0.0113 & 0.0017 & \multirow{2}{*}{0.0000} & $-221.51 \%$ \\
\hline & -0.0282 & -0.0154 & -0.0026 & 0.0041 & 0.0063 & -0.0072 & & $-122.34 \%$ \\
\hline \multirow{2}{*}{ RD } & 0.0203 & 0.0201 & 0.0203 & 0.0205 & 0.0207 & 0.0204 & \multirow{2}{*}{0.0000} & $1.97 \%$ \\
\hline & 0.0067 & 0.0068 & 0.0071 & 0.0071 & 0.0073 & 0.0070 & & $8.96 \%$ \\
\hline & 0.2049 & 0.2068 & 0.2129 & 0.2134 & 0.2130 & 0.2102 & & $3.95 \%$ \\
\hline TAX & 0.1566 & 0.1608 & 0.1666 & 0.1677 & 0.1707 & 0.1645 & 0.0000 & $9.00 \%$ \\
\hline & 0.4258 & 0.4267 & 0.4314 & 0.4333 & 0.4313 & 0.4297 & & $1.29 \%$ \\
\hline REV & 0.2715 & 0.2749 & 0.2825 & 0.2852 & 0.2893 & 0.2807 & 0.0529 & $6.56 \%$ \\
\hline & 1.1775 & 1.2281 & 1.3458 & 1.4122 & 1.4426 & 1.3212 & & $22.51 \%$ \\
\hline CRED & 0.4805 & 0.4988 & 0.5291 & 0.5693 & 0.5970 & 0.5349 & 0.0022 & $24.25 \%$ \\
\hline & 0.2389 & 0.2496 & 0.2494 & 0.2485 & 0.2464 & 0.2466 & & $3.14 \%$ \\
\hline FDGDP & 0.2222 & 0.2206 & 0.1863 & 0.1822 & 0.1606 & 0.1944 & 0.0000 & $-27.72 \%$ \\
\hline & 0.5993 & 0.5995 & 0.5965 & 0.5762 & 0.5527 & 0.5848 & & $-7.78 \%$ \\
\hline PDGDP & 0.5140 & 0.4835 & 0.4505 & 0.4168 & 0.3866 & 0.4503 & 0.0000 & $-24.79 \%$ \\
\hline & 2.0353 & 1.7829 & 2.1383 & 2.4042 & 2.2945 & 2.1310 & & $12.74 \%$ \\
\hline INFL & 4.8473 & 4.6471 & 5.3869 & 5.5072 & 5.7830 & 5.2343 & 0.0000 & $19.30 \%$ \\
\hline & 0.0629 & 0.0639 & 0.0625 & 0.0592 & 0.0538 & 0.0605 & & $-14.47 \%$ \\
\hline UNPL & 0.0961 & 0.0929 & 0.0853 & 0.0773 & 0.0693 & 0.0842 & 0.0000 & $-27.89 \%$ \\
\hline & 0.9402 & 0.9438 & 0.9484 & 0.9494 & 0.9538 & 0.9471 & & $1.45 \%$ \\
\hline HDI & 0.7835 & 0.7906 & 0.8008 & 0.8044 & 0.8126 & 0.7984 & 0000 & $3.71 \%$ \\
\hline & 8.0130 & 8.0043 & 8.0609 & 7.9000 & 7.8417 & 7.9640 & & $-2.14 \%$ \\
\hline CRPT & 4.2615 & 4.2795 & 4.3333 & 4.3368 & 4.4158 & 4.3254 & 0.0000 & $3.62 \%$ \\
\hline & 5.1974 & 5.2335 & 5.1170 & 5.2792 & 5.1213 & 5.1897 & & $-1.46 \%$ \\
\hline COMP & 4.1818 & 4.2500 & 4.1082 & 4.3645 & 4.3458 & 4.2501 & 0.0000 & $3.92 \%$ \\
\hline & 71.7391 & 71.5913 & 71.72609 & 72.6375 & 72.8458 & 72.1080 & 00000 & $1.54 \%$ \\
\hline FRDM & 64.2205 & 64.3897 & 63.5949 & 63.9342 & 64.1894 & 64.0657 & 0.0000 & $-0.05 \%$ \\
\hline
\end{tabular}

The t-test column gives the p-value associated with a Student's t-test (assuming unequal variances) of the difference in averages between OECD and non-OECD countries across all years. 
Table 3. Correlation Analysis

\begin{tabular}{|c|c|c|c|c|c|c|}
\hline & RTGSP & RTGF & RTGM & YTM & SPREAD & INFRM \\
\hline RTGF & $0.9933^{*}$ & & & & & \\
\hline RTGM & $0.9792 *$ & $0.9802 *$ & & & & \\
\hline YTM & $0.6297 *$ & $0.6360 *$ & $0.6169 *$ & & & \\
\hline SPREAD & $0.6124 *$ & $0.6186^{*}$ & $0.5945^{*}$ & $0.9341 *$ & & \\
\hline INFRM & $0.7710^{*}$ & $0.7730 *$ & $0.7705^{*}$ & $0.4198 *$ & $0.3944^{*}$ & \\
\hline GNI & $-0.455^{*}$ & $-0.4712 *$ & $-0.4357 *$ & $-0.1976^{*}$ & $-0.2062 *$ & $-0.4806^{*}$ \\
\hline GDPG & $0.3352 *$ & $0.3376^{*}$ & $0.3432 *$ & 0.0472 & -0.0014 & $0.2889^{*}$ \\
\hline BLNC & $-0.2000 *$ & $-0.1934 *$ & $-0.1253 *$ & -0.0867 & -0.0916 & $-0.1748^{*}$ \\
\hline DFCT & $-0.3294 *$ & $-0.3205^{*}$ & $-0.2758 *$ & $-0.1757 *$ & $-0.1953 *$ & $-0.1889 *$ \\
\hline RD & $-0.7036^{*}$ & $-0.7062 *$ & $-0.7298 *$ & $-0.3906^{*}$ & $-0.3843^{*}$ & $-0.6595^{*}$ \\
\hline TAX & $-0.3937 *$ & $-0.3829 *$ & $-0.3709 *$ & $-0.1419 *$ & $-0.1450 *$ & $-0.3141 *$ \\
\hline REV & $-0.6401 *$ & $-0.6307 *$ & $-0.6438 *$ & $-0.2794 *$ & $-0.296^{*}$ & $-0.4809 *$ \\
\hline CRED & $-0.6704 *$ & $-0.6917 *$ & $-0.6831 *$ & $-0.4243 *$ & $-0.3947 *$ & $-0.5910 *$ \\
\hline FDGDP & $0.2238^{*}$ & $0.2237^{*}$ & $0.2180 *$ & $0.1811 *$ & $0.2169 *$ & $0.2268^{*}$ \\
\hline PDGDP & $0.1163^{*}$ & 0.0982 & 0.0627 & 0.0301 & 0.0671 & -0.0103 \\
\hline INFL & $0.5780 *$ & $0.5916^{*}$ & $0.5844 *$ & $0.7270 *$ & $0.6927 *$ & $0.3900 *$ \\
\hline UNPL & $0.3116^{*}$ & $0.3158^{*}$ & $0.3083^{*}$ & $0.3130 *$ & $0.2954 *$ & $0.3033^{*}$ \\
\hline HDI & $-0.7788^{*}$ & $-0.7814 *$ & $-0.7824 *$ & $-0.5012^{*}$ & $-0.4927^{*}$ & $-0.6073 *$ \\
\hline CRPT & $-0.8680 *$ & $-0.8669 *$ & $-0.8563^{*}$ & $-0.4623^{*}$ & $-0.4506^{*}$ & $-0.7452 *$ \\
\hline COMP & $-0.8823 *$ & $-0.8817 *$ & $-0.8771 *$ & $-0.5566^{*}$ & $-0.5527 *$ & $-0.7375^{*}$ \\
\hline FRDM & $-0.6162 *$ & $-0.6083^{*}$ & $-0.6057 *$ & $-0.4044^{*}$ & $-0.3826^{*}$ & $-0.5559 *$ \\
\hline
\end{tabular}

A star denotes statistically significant values at the $5 \%$ level using a two-tailed test. 
Table 4. Baseline regression for all countries.

\begin{tabular}{|c|c|c|c|c|c|}
\hline Dependent: & RTGSP & RTGF & RTGM & YTM & SPREAD \\
\hline INFRM & $2.5478^{*}$ & $1.9196^{\dagger}$ & $2.1627^{\dagger}$ & $3.7892^{\dagger}$ & $3.5095^{\dagger}$ \\
\hline INFL & $0.1233^{*}$ & $0.0691 *$ & $0.1373^{*}$ & $0.6885^{*}$ & $0.6585^{*}$ \\
\hline GNI & & & $-0.1250^{\dagger}$ & $0.4844 *$ & \\
\hline GDPG & & & & $-19.2001 *$ & $-24.595^{*}$ \\
\hline BLNC & $-5.3500 *$ & & $-6.0059^{*}$ & $-5.2383^{\dagger}$ & \\
\hline DFCT & $-10.3572 *$ & $-6.9289 *$ & $-11.7818 *$ & $-15.1781 *$ & $-16.826^{*}$ \\
\hline TAX & & & & $5.8662^{\dagger}$ & \\
\hline CRED & & & $-0.6245^{*}$ & $-1.0944 *$ & \\
\hline FDGDP & & $1.0209^{\dagger}$ & & & \\
\hline PDGDP & $1.3063^{*}$ & & $1.2768^{*}$ & & \\
\hline UNPL & & & & $11.0297^{*}$ & $13.593^{*}$ \\
\hline HDI & $-3.9977^{*}$ & $-2.7557^{\dagger}$ & $-3.5118^{*}$ & & \\
\hline CRPT & $-0.3517 *$ & $-0.3049 *$ & $-0.3642 *$ & $0.7265 *$ & \\
\hline COMP & $-1.4522^{*}$ & $-1.3808^{*}$ & $-1.3186^{*}$ & $-1.1437^{*}$ & $-0.24831 *$ \\
\hline Non-OECD & $2.5082 *$ & $2.6625^{*}$ & $2.5439 *$ & $2.0389 *$ & \\
\hline EURO & $-2.7606^{*}$ & $-1.5517^{*}$ & $-2.8913^{*}$ & $-2.1248^{*}$ & $-1.9047^{*}$ \\
\hline DFLT95 & $0.6854^{*}$ & $0.4779^{\dagger}$ & $0.5727^{*}$ & $-1.0050^{\dagger}$ & \\
\hline DFLT75 & & 0.2756 & & & \\
\hline FRDM & & & & $-0.0480^{\dagger}$ & \\
\hline LGLUK & $-1.3040^{*}$ & & & & \\
\hline LGLGRM & $-1.3019^{*}$ & & & & \\
\hline LGLFRC & & $1.0057 *$ & $1.1525^{*}$ & $0.9124^{\dagger}$ & \\
\hline LGLSKN & $1.1969^{*}$ & -6.0802 & $2.3524 *$ & $2.3172 *$ & $2.1839 *$ \\
\hline LGLSOC & $-2.1350^{*}$ & $-0.9730 *$ & $-1.0991^{*}$ & $-1.9428^{*}$ & $-2.1675^{*}$ \\
\hline$\overline{\mathbf{R}^{2}}$ & 0.5244 & 0.4661 & 0.5187 & 0.7185 & 0.6413 \\
\hline
\end{tabular}


Table 5. Regression analysis for subsample of 24 OECD countries.

\begin{tabular}{|c|c|c|c|c|c|}
\hline Dependent: & RTGSP & RTGF & RTGM & YTM & SPREAD \\
\hline INFRM & $21.0024 *$ & $58.9674 *$ & $39.0428 *$ & $3.8977^{\dagger}$ & $4.6145^{\dagger}$ \\
\hline GNI & $-1.2943 *$ & $-0.6786^{\dagger}$ & $-0.7331 *$ & $-0.1951 *$ & $-0.1999 *$ \\
\hline BLNC & $-12.4950 *$ & $20.0940^{\dagger}$ & & $-6.6113^{*}$ & $-3.8955^{*}$ \\
\hline DFCT & $-19.2134 *$ & $-51.6560^{\dagger}$ & $-32.6008 *$ & $-7.8839 *$ & $-11.5422 *$ \\
\hline TAX & & & $8.8708^{\dagger}$ & & \\
\hline REV & & & $-8.0694^{\dagger}$ & $6.9147 *$ & $8.0173 *$ \\
\hline PDGDP & $3.3803 *$ & & $2.5390 *$ & $-1.5976^{*}$ & $-1.6009 *$ \\
\hline INFL & & & $0.5743^{*}$ & & 0.1668 \\
\hline HDI & & $-74.6787 *$ & & $5.2684^{*}$ & \\
\hline CRPT & $-1.4126^{*}$ & & & & \\
\hline COMP & & $-3.7738^{\dagger}$ & & & \\
\hline EURO & $-3.9539 *$ & $-3.4246^{\dagger}$ & $-4.6089 *$ & $-1.4110^{*}$ & $-1.6966^{*}$ \\
\hline LGLUK & $-1.8803^{*}$ & & $-1.8300^{\dagger}$ & & \\
\hline LGLFRC & $-2.0987^{\dagger}$ & & & & \\
\hline LGLSOC & & & & $-2.2365^{*}$ & $-3.0528 *$ \\
\hline $\mathbf{R}^{2}$ & 0.6591 & 0.8289 & 0.6217 & 0.7696 & 0.7293 \\
\hline
\end{tabular}

A star (dagger) denotes statistical significance at the 1\% (5\%) level. The models for RTGSP, RTGF and RTGM are estimated via maximum likelihood using pooled ordered probit regression; for the remaining OLS was used.

Table 6. Regression analysis for subsample of 41 non-OECD countries

\begin{tabular}{|c|c|c|c|c|c|}
\hline Dependent: & RTGSP & RTGF & RTGM & YTM & SPREAD \\
\hline INFRM & $2.1827^{\dagger}$ & $2.7813^{*}$ & $2.7773^{*}$ & $5.0046^{\dagger}$ & 0.3463 \\
\hline BLNC & $-6.0721 *$ & 0.3715 & $-7.3495 *$ & & \\
\hline DFCT & $-9.1665^{*}$ & $-5.6180 *$ & $-9.7511 *$ & $-17.5786^{*}$ & $-11.0268^{\dagger}$ \\
\hline GNI & & $0.1513^{*}$ & & $0.5333^{*}$ & $0.3340 *$ \\
\hline GDPG & & & & $-29.9026^{*}$ & $-39.9374 *$ \\
\hline RD & & $-29.9962^{\dagger}$ & & & \\
\hline TAX & & 2.8629 & $4.3876^{\dagger}$ & & \\
\hline CRED & & & $-1.0058^{*}$ & $-1.7708^{\dagger}$ & \\
\hline FDGDP & & & & & $3.0501^{\dagger}$ \\
\hline PDGDP & $1.4163^{*}$ & & $1.3634^{*}$ & & \\
\hline INFL & $0.1292 *$ & $0.0639 *$ & $0.1336^{*}$ & $0.6494 *$ & $0.6026^{*}$ \\
\hline UNPL & & & & $16.4747 *$ & $12.2627 *$ \\
\hline HDI & $-2.8889^{\dagger}$ & & & & \\
\hline CRPT & $-0.3573^{*}$ & & $-0.5354 *$ & $0.4714^{\dagger}$ & \\
\hline COMP & $-1.4790 *$ & $-1.8291 *$ & $-1.0615^{*}$ & & \\
\hline EURO & $-3.4629 *$ & & $-4.7506^{*}$ & & \\
\hline DFLT95 & $0.8070 *$ & $0.3918^{\dagger}$ & $0.6535^{*}$ & $-1.5754^{*}$ & $-1.4968 *$ \\
\hline FRDM & & & & $-0.0862^{*}$ & $-0.0679 *$ \\
\hline LGLUK & & & $1.8323^{*}$ & $1.4659 *$ & $1.2622^{\dagger}$ \\
\hline LGLFRC & $1.1261 *$ & & $2.4505^{*}$ & $2.7289 *$ & $2.4600 *$ \\
\hline LGLSOC & $-1.2211^{*}$ & & & & \\
\hline$\overline{\mathbf{R}^{2}}$ & 0.4333 & 0.2496 & 0.4383 & 0.7071 & 0.6637 \\
\hline
\end{tabular}

A star (dagger) denotes statistical significance at the 1\% (5\%) level. The models for RTGSP, RTGF and RTGM are estimated via maximum likelihood using pooled ordered probit regression; for the remaining OLS was used. 
Table 7. Principal Component Analysis (PCA)

\begin{tabular}{|c|c|c|c|c|c|c|c|}
\hline & \multicolumn{7}{|c|}{ Principal Component } \\
\hline & 1 & 2 & 3 & 4 & 5 & 6 & 7 \\
\hline Eigenvalue & 7.9288 & 2.8233 & 2.1920 & 1.7006 & 1.4431 & 1.1355 & 1.0890 \\
\hline Difference & 5.1055 & 0.6313 & 0.4914 & 0.2575 & 0.3076 & 0.0466 & 0.1893 \\
\hline Proportion & 0.3172 & 0.1129 & 0.0877 & 0.0680 & 0.0577 & 0.0454 & 0.0436 \\
\hline Cumulative Value & 7.9288 & 10.7521 & 12.9442 & 14.6448 & 16.0879 & 17.2235 & 18.3124 \\
\hline \multirow[t]{2}{*}{ Cumulative Proportion } & 0.3172 & 0.4301 & 0.5178 & 0.5858 & 0.6435 & 0.6889 & 0.7325 \\
\hline & \multicolumn{7}{|c|}{ Eigenvector loadings } \\
\hline GNI & 0.1780 & 0.1724 & -0.2204 & -0.0228 & 0.1707 & -0.0479 & 0.4016 \\
\hline GDPG & -0.1618 & -0.2656 & 0.0618 & 0.1020 & 0.1343 & -0.2728 & -0.3536 \\
\hline BLNC & 0.0510 & -0.1213 & -0.1056 & 0.4936 & 0.3688 & 0.1904 & -0.0384 \\
\hline DFCT & 0.0841 & -0.3345 & 0.2147 & 0.3619 & 0.1316 & 0.0556 & 0.0174 \\
\hline RD & 0.2926 & 0.0138 & -0.0515 & -0.0705 & 0.0815 & $\mathbf{0 . 3 1 3 7}$ & -0.0466 \\
\hline TAX & 0.1622 & -0.0628 & 0.3278 & 0.0889 & -0.3049 & 0.0101 & 0.0338 \\
\hline REV & 0.2371 & 0.0492 & 0.4023 & -0.0766 & 0.0332 & 0.1356 & -0.0082 \\
\hline CRED & 0.2728 & 0.0105 & -0.1264 & -0.0185 & -0.1415 & -0.1259 & 0.1453 \\
\hline FDGDP & -0.0467 & 0.4136 & 0.1069 & 0.1306 & -0.2106 & 0.0633 & -0.4175 \\
\hline PDGDP & 0.0270 & 0.4175 & -0.2529 & 0.0313 & -0.0825 & 0.1983 & -0.2888 \\
\hline INFL & -0.2133 & -0.0178 & 0.1143 & 0.1877 & -0.0256 & 0.0867 & -0.0203 \\
\hline UNPL & -0.1311 & 0.0532 & 0.1082 & -0.1138 & -0.2278 & 0.4733 & 0.2956 \\
\hline HDI & 0.2882 & 0.0283 & 0.0941 & -0.1250 & 0.2005 & -0.1990 & -0.0027 \\
\hline CRPT & 0.3260 & -0.0786 & 0.0326 & 0.0876 & -0.0350 & 0.0196 & 0.0248 \\
\hline COMP & 0.3216 & -0.1307 & -0.0602 & -0.0044 & 0.1015 & 0.0201 & 0.0116 \\
\hline EURO & 0.1986 & 0.2818 & 0.2177 & 0.0638 & -0.0135 & -0.1053 & 0.0590 \\
\hline NONOECD & -0.2984 & -0.1827 & -0.0654 & -0.0418 & 0.0632 & 0.0526 & -0.0976 \\
\hline DFLT95 & -0.1780 & 0.0622 & 0.1342 & 0.0136 & 0.2348 & 0.1878 & 0.2077 \\
\hline DFLT75 & -0.2505 & 0.0320 & 0.1257 & 0.0515 & 0.1014 & 0.2011 & 0.3778 \\
\hline FRDM & 0.2234 & -0.1875 & -0.0876 & -0.0476 & -0.1236 & -0.1097 & 0.0564 \\
\hline LGLUK & 0.0145 & -0.2487 & -0.3628 & 0.2086 & -0.4797 & 0.0753 & 0.0906 \\
\hline LGLFRC & -0.1069 & 0.3634 & 0.1591 & 0.2609 & 0.1355 & -0.3960 & 0.2147 \\
\hline LGLGRM & 0.1097 & 0.0812 & -0.2900 & -0.1329 & 0.4248 & 0.2796 & -0.1775 \\
\hline LGLSKN & 0.1670 & -0.0549 & 0.3252 & 0.1484 & -0.0316 & 0.3056 & -0.2092 \\
\hline LGLSOC & -0.0837 & -0.1937 & 0.2209 & -0.5862 & 0.0922 & -0.0150 & -0.0976 \\
\hline
\end{tabular}

Eigenvalue loadings with a value which exceeds 0.2 in absolute value are formatted in bold. 
Table 8. Regression analysis using principal components

\begin{tabular}{lccccc}
\hline Dependent: & RTGSP & RTGF & RTGM & YTM & SPREAD \\
\hline INFRM & $1.6482^{\dagger}$ & $1.7741^{\dagger}$ & $1.6740^{\dagger}$ & -4.1085 & -4.8453 \\
P1 & $-0.9385^{*}$ & $-1.0621^{*}$ & $-0.9665^{*}$ & $-1.0026^{*}$ & $-0.9759^{*}$ \\
P2 & $0.2418^{*}$ & $0.2358^{*}$ & $0.1966^{*}$ & $0.4379^{*}$ & $0.4987^{*}$ \\
P3 & $-0.1315^{*}$ & $-0.2159^{*}$ & $-0.1046^{\dagger}$ & $0.2959^{\dagger}$ & \\
P4 & & $0.1349^{*}$ & & $0.6870^{*}$ & $0.6556^{*}$ \\
P5 & $-0.1594^{*}$ & & $-0.2035^{*}$ & $-0.5657^{*}$ & $-0.6744^{*}$ \\
P6 & $0.1258^{\dagger}$ & & $0.1517^{\dagger}$ & $0.7827^{*}$ & $0.7639^{*}$ \\
P7 & $-0.1876^{*}$ & & $-0.2170^{*}$ & $0.4407^{\dagger}$ & \\
Constant & & & & $7.4660^{*}$ & $3.2177^{*}$ \\
$\mathbf{R}^{2}$ & 0.3888 & 0.4172 & 0.3881 & 0.4424 & 0.4201 \\
\hline A star (dagser
\end{tabular}

A star (dagger) denotes statistical significance at the $1 \%$ (5\%) level. The models for RTGSP, RTGF and RTGM are estimated via maximum likelihood using pooled ordered probit regression; for the remaining OLS was used.

Table 9. Variable importance analysis from Multilayer-Perceptron (MLP) models

\begin{tabular}{lccccc}
\hline & RTGSP & RTGF & RTGM & YTM & SPREAD \\
\hline INFRM & $0.9569(4)$ & $0.5990(7)$ & $0.7238(7)$ & $0.0952(12)$ & $0.0607(13)$ \\
BLNC & $0.9144(5)$ & $0.7488(3)$ & $0.5466(14)$ & $0.2083(2)$ & $0.1021(10)$ \\
COMP & $0.2932(17)$ & $0.3458(14)$ & $0.5788(11)$ & $0.0615(16)$ & $0.1937(5)$ \\
CRED & $0.6548(10)$ & $0.5979(8)$ & $0.8820(2)$ & $0.1225(8)$ & $0.0653(12)$ \\
CRPT & $0.7165(9)$ & $0.6984(4)$ & $0.7073(8)$ & $0.0547(17)$ & $0.0287(21)$ \\
DEV & $0.1820(23)$ & $0.1938(21)$ & $0.4345(18)$ & $0.0182(26)$ & $0.0155(24)$ \\
DFCT & $0.8269(7)$ & $0.6337(6)$ & $0.5492(12)$ & $0.1920(3)$ & $0.2251(4)$ \\
DFLT75 & $0.1828(22)$ & $0.1389(25)$ & $0.2391(22)$ & $0.0130(27)$ & $0.0193(23)$ \\
DFLT95 & $0.2806(18)$ & $0.1910(22)$ & $0.2826(20)$ & $0.0450(18)$ & $0.0431(16)$ \\
EURO & $0.2010(21)$ & $0.1530(24)$ & $0.0872(27)$ & $0.0235(24)$ & $0.0357(18)$ \\
FDGDP & $0.9736(2)$ & $0.3949(13)$ & $1.0000(1)$ & $0.1579(6)$ & $0.0797(11)$ \\
FRDM & $0.5771(14)$ & $0.1889(23)$ & $0.5233(15)$ & $0.1198(9)$ & $0.0424(17)$ \\
GDPG & $0.9660(3)$ & $0.4704(10)$ & $0.7325(6)$ & $0.1863(4)$ & $0.4020(2)$ \\
GNI & $0.8893(6)$ & $0.2467(17)$ & $0.5471(13)$ & $0.1770(5)$ & $0.1718(6)$ \\
HDI & $0.5676(15)$ & $0.6711(5)$ & $0.4926(17)$ & $0.0978(11)$ & $0.1021(9)$ \\
IND & $0.1673(25)$ & $0.2162(20)$ & $0.4038(19)$ & $0.0222(25)$ & $0.0119(26)$ \\
INFL & $0.6044(12)$ & $1.0000(1)$ & $0.6074(10)$ & $1.0000(1)$ & $1.0000(1)$ \\
LGLFRC & $0.2311(20)$ & $0.2429(18)$ & $0.1261(24)$ & $0.0718(14)$ & $0.0521(14)$ \\
LGLGRM & $0.1462(26)$ & $0.2168(19)$ & $0.1117(26)$ & $0.0319(20)$ & $0.0305(19)$ \\
LGLSKN & $0.1282(27)$ & $0.0697(26)$ & $0.1181(25)$ & $0.0707(15)$ & $0.0135(25)$ \\
LGLSOC & $0.1774(24)$ & $0.2723(16)$ & $0.2491(21)$ & $0.0251(23)$ & $0.0301(20)$ \\
LGLUK & $0.2627(19)$ & $0.0274(27)$ & $0.1491(23)$ & $0.0254(22)$ & $0.0280(22)$ \\
PDGDP & $1.0000(1)$ & $0.8028(2)$ & $0.7332(5)$ & $0.0778(13)$ & $0.1045(8)$ \\
RD & $0.7853(8)$ & $0.4659(11)$ & $0.7644(4)$ & $0.0315(21)$ & $0.0488(15)$ \\
REV & $0.6443(11)$ & $0.5081(9)$ & $0.6238(9)$ & $0.0429(19)$ & $0.0095(27)$ \\
TAX & $0.5038(16)$ & $0.2899(15)$ & $0.5027(16)$ & $0.1470(7)$ & $0.1610(7)$ \\
UNPL & $0.6043(13)$ & $0.3971(12)$ & $0.8427(3)$ & $0.1014(10)$ & $0.2343(3)$ \\
\hline The tabe $p$ & & &
\end{tabular}

The table presents normalised importance values obtained via simulation. The normalisation is obtained by dividing the each importance value with the largest importance value. Numbers in brackets denote the rank in terms of importance analysis with 1 being the most important variable. 
Figure 1. Scatterplot between S\&P credit rating and informal sector.

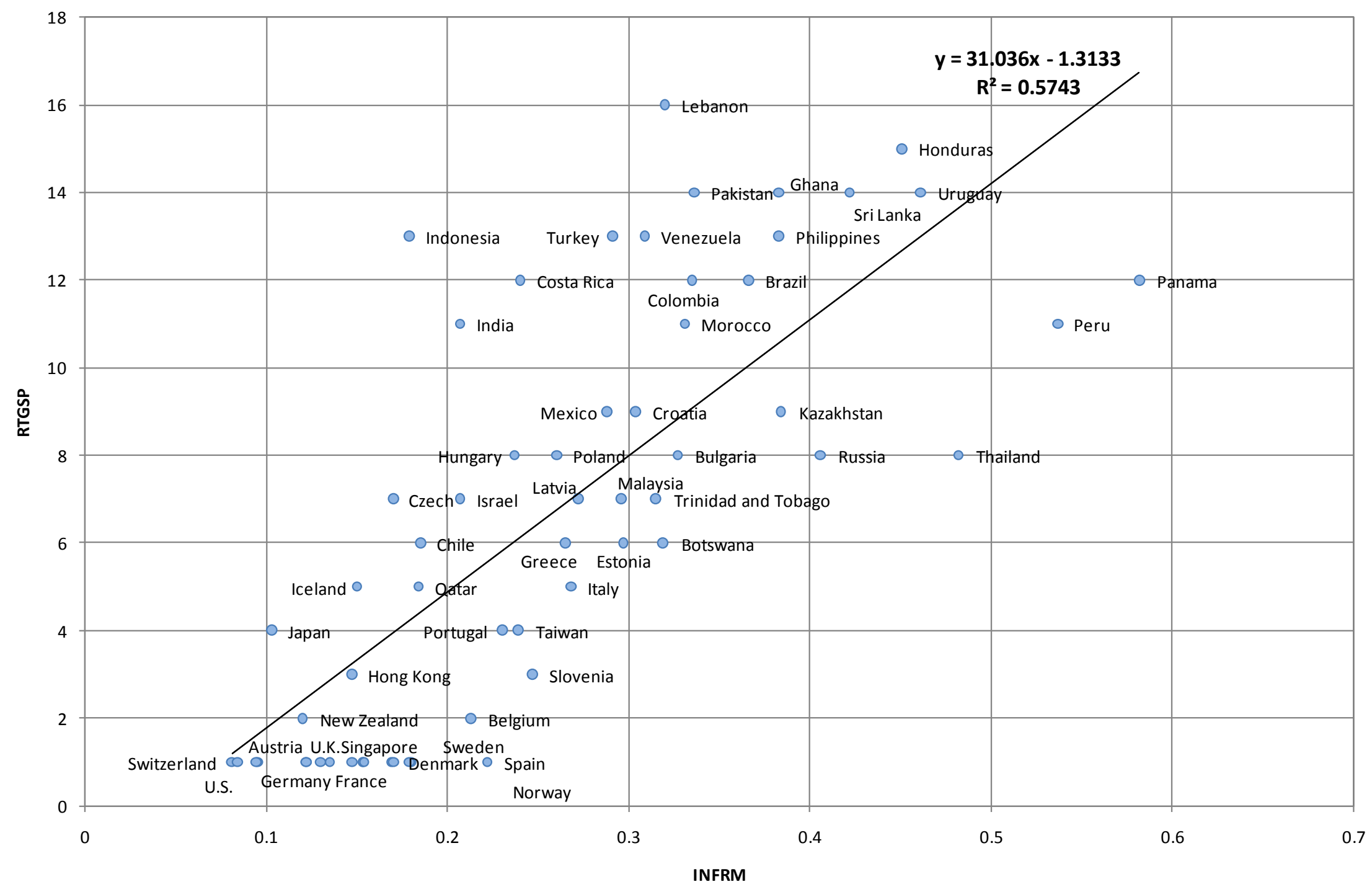


Figure 2. Scatterplot between YTM and informal sector.

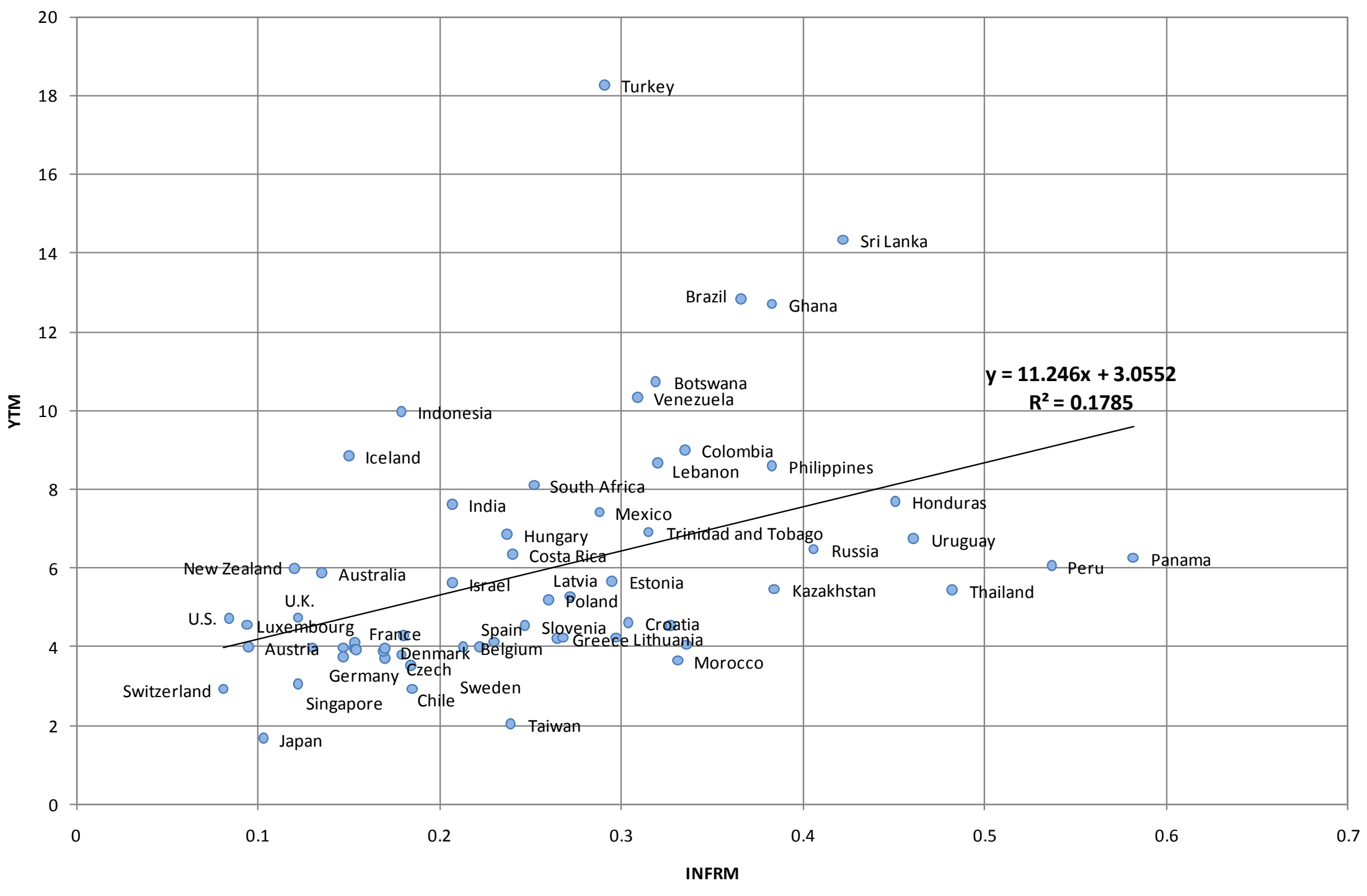


Figure 3. Moody's rating classification as investment grade or junk using a CHAID decision tree. The tree considers classification in two classes: investment grade (INVG) and junk (JNK)

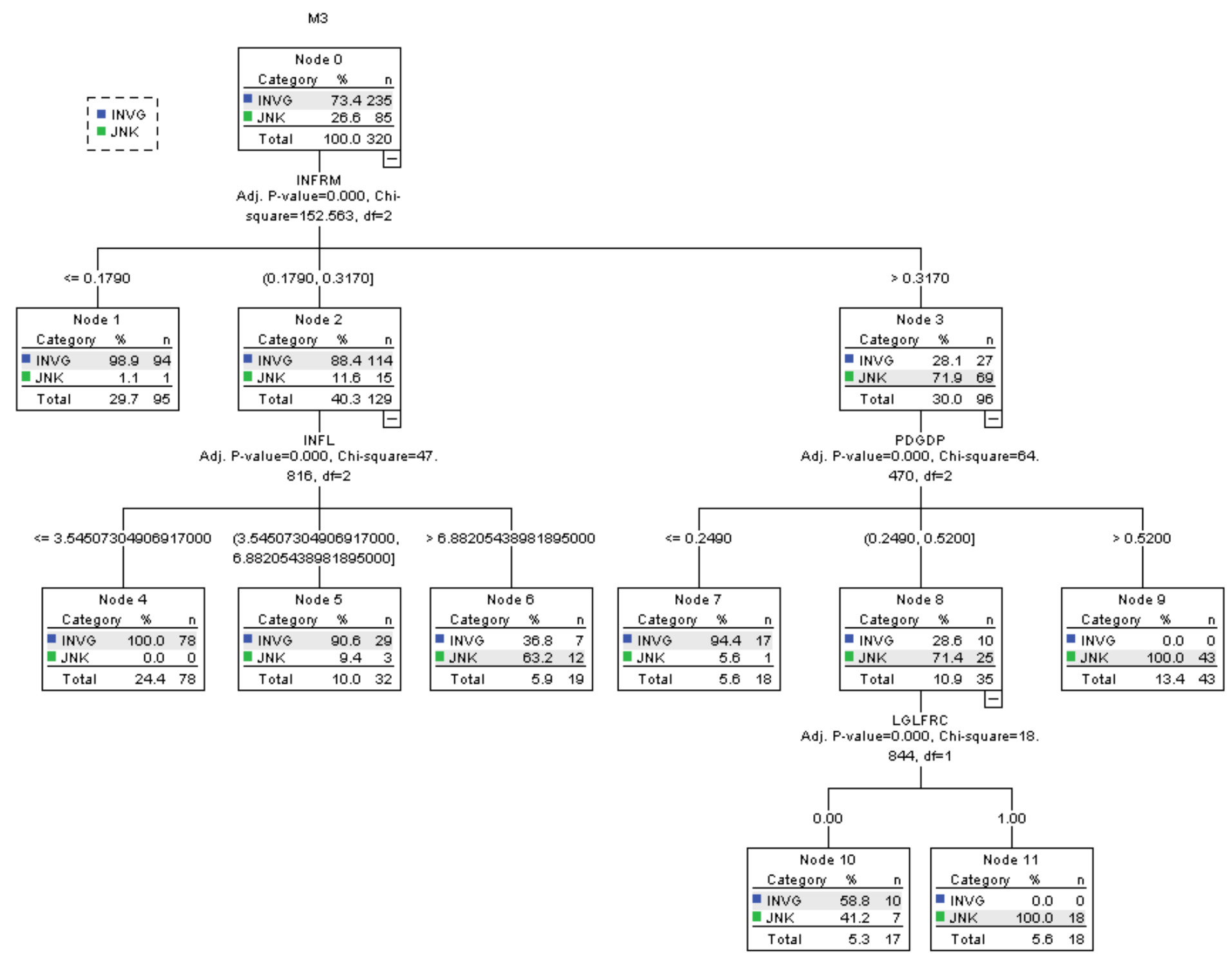

